\title{
Evaluation of Finger Photoplethysmography Fitness Index on Young Women with Cardiovascular Disease Risk Factors
}

(Penilaian Kesihatan Fotopletismografi Jari Telunjuk Wanita Muda dengan Risiko Faktor Penyakit Kardiovaskular)

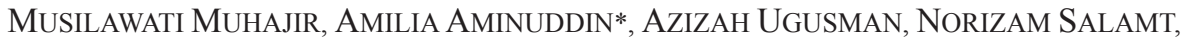 \\ ZANARIYAH ASMAWI, AINI FARZANA ZULKEFLI, MUHAMMAD FIRDAUS AZMI, \\ KALAIVANI CHELLAPPAN \& NOR ANITA MEGAT MOHD NORDIN
}

\begin{abstract}
The use of photoplethysmography (PPG) as one of cardiovascular disease (CVD) marker has got more attention due to its simplicity, noninvasive and portable characteristics. Two new markers had been developed from PPG namely PPG fitness index (PPGF) and vascular risk prediction index (VPRI). The aim of the present study was to compare PPGF level between young women with and without CVD risk factors, to investigate the relationship between PPGF with other CVD markers and to assess the sensitivity of VRPI in classifying young women that have CVD risk factors. A total of 148 young women aged 20-40 years old with and without CVD risk factors were involved in this study. CVD risk factors comprised of abdominal obesity, hypertension, dyslipidemia, smoking and family history of premature CVD. Subjects were categorized into healthy or having CVD risk factor. Measurements taken were anthropometric data, blood pressure, lipid profile, pulse wave velocity (PWV), augmentation index (AIX), high sensitivity C-Reactive Protein (hs-CRP), PPGF and VRPI. SPSS version 20 was used for data analysis with $\mathrm{p}<0.05$ as significant value. The mean subjects'age was $29.97 \pm 5.27$ years old. There was no difference in PPGF level between groups $(\mathrm{p}>0.05)$. PPGF was independently determined by PWV $(\beta=-$ $0.31, \mathrm{p}<0.001)$ and height $(\beta=0.16, \mathrm{p}=0.04)$. VRPI had $77.9 \%$ sensitivity in identifying subjects with CVD risk factor. In conclusion, PPGF correlates with PWV and has potential to be an indicator of aortic stiffness while VRPI is sensitive to classify those with CVD risk factor.
\end{abstract}

Keywords: Cardiovascular disease; photoplethysmography; pulse wave velocity; women

\section{ABSTRAK}

Penggunaan fotopletismografi (PPG) sebagai salah satu penanda penyakit kardiovaskuar (CVD) semakin mendapat perhatian kerana ciri-cirinya yang ringkas, tidak invasif dan mudah alih. Dua penanda telah dibangunkan daripada PPG yang dinamakan indeks kecergasan PPG (PPGF) dan indeks jangkaan risiko saluran darah (VPRI). Tujuan kajian ini adalah untuk membandingkan tahap PPGF antara wanita muda yang sihat dan yang mempunyai faktor risiko CVD, menentukan hubungan antara PPGF dengan lain-lain penanda CVD dan menilai kesensitifan VRPI dalam mengenal pasti wanita muda yang mempunyai faktor risiko CVD. Seramai 148 orang wanita muda dengan julat umur 20-40 tahun yang sihat atau yang mempunyai faktor risiko CVD telah terlibat dalam kajian ini. Faktor risiko CVD adalah obesiti abdomen, hipertensi, dislipidemia, merokok dan sejarah keluarga dengan CVD pramatang. Subjek dikategorikan kepada kumpulan sihat atau mempunyai faktor risiko CVD. Pengukuran yang diambil ialah data antropometrik, tekanan darah, profil lipid, halaju gelombang nadi (PWV), indeks augmentasi (AIx), Protein C-Reaktifberkesensitifan tinggi (hs-CRP), PPGF dan VRPI. SPSS versi 20 telah digunakan untuk menganalisis data dengan $\mathrm{p}<0.05$ sebagai had signifikan. Purata umur subjek ialah $29.97 \pm 5.27$ tahun. Tiada perbezaan yang signifikan pada PPGF antara kumpulan ( $>00.05)$. PPGF ditentukan secara bebas oleh $P W V($ Beta $=-0.31, \mathrm{p}<0.001)$ dan tinggi (Beta=0.16, $\mathrm{p}=0.04)$. VRPI mempunyai $77.9 \%$ kesensitifan dalam mengenal pasti subjek yang mempunyai faktor risiko CVD. Kesimpulannya, PPGF mempunyai hubungan dengan PWV dan mempunyai potensi sebagai indikator kekerasan aorta manakala VRPI adalah sensitif dalam mengesan faktor risiko CVD.

Kata kunci: Fotopletismograf; halaju gelombang nadi; penyakit kardiovaskular; wanita

\section{INTRODUCTION}

Cardiovascular disease (CVD) is an important cause of death globally with estimation of 17 million deaths peryear (Borhanuddin et al. 2018). Coronary heart disease and stroke are the most common cause of CVD deaths compared to other forms of CVDs. It is reported that $82 \%$ of these deaths occur in low-and-middle income countries while the developed countries show decreasing trend (Chin \& Pengal 2009; WHO 2017). In Malaysia, the CVD death account $36 \%$ and it is also a major cause of death among women (Gupta et al. 2013; WHO 2014). Hypertension, obesity, smoking, diabetes mellitus, dyslipidemia, stress and diet are the modifiable CVD risk factors while age, gender and positive family history are non-modifiable risk factors 
(Gafor et al. 2018; Gupta et al. 2013; WHO 2011). Another study showed that only $50 \%$ of young women and less than $40 \%$ of young men undergo CVD screening (Kuklina et al. 2010). The importance of CVD risk factor screening among the young is highlighted in the National Cholesterol Education Program Adult Treatment Panel III (NCEP ATP III). They suggested for high cholesterol screening at age of 20 years as this risk may track into adulthood.

Several conventional CVD risk factors have been used to develop algorithms that predict the future risk of getting CVD. However, these algorithms are still lacking in the accuracy and not correlated well to the CVD incidents (Veeranna et al. 2010). The understanding in the pathogenesis of atherosclerosis has highlighted new CVD risk markers to improve CVD risk prediction such as C-Reactive Protein (CRP), pulse wave velocity (PWV) and augmentation index (AIx) (Arnold et al. 2017; Gamil et al. 2014; Ring et al. 2014). CRP is an inflammatory marker and many studies had shown the linkage between longterm low-grade inflammations with CVD events (Gamil et al. 2014; Shyam et al. 2014). In addition, the Reynolds Risk Score (RRS) incorporated CRP and family history to conventional CVD risk factors available in the Framingham Risk Score (FRS) for better CVD risk prediction (DeFilippis et al. 2011). PWV and AIX are both arterial stiffness markers and many studies showed their connection with CVD incidents (Ring et al. 2014). Previous studies showed that PWV can be used as predictor of coronary artery disease (Luo et al. 2014) while augmentation index was demonstrated as predictors of myocardial infarction, coronary heart disease and stroke (Chirinos et al. 2012). However, there are some limitations on the usage of such markers, especially on large-scale population. CRP is an invasive method that may cause discomfort during blood taking while PWV and AIx are measured using an expensive device. Therefore, finger photoplethysmography (PPG) was introduced as another form of CVD risk markers, which is less expensive, user friendly and portable (Usman et al. 2014).

Recent studies have been focusing on PPG to access CVD risk (Kuznetsova et al. 2014; Tabara et al. 2016). It consists of an infrared light source and a photodetector making it a simple and non-invasive device. The opticalelectronic is used to illuminate the skin and the amount of light that is transmitted or reflected will be captured by the photodetector (Allen 2007; Elgendi 2012). PPG operates by detecting the blood volume changes in the microvascular bed of tissue. Therefore, the data obtained from PPG is in waveform signal (Usman et al. 2014). Previously, PPG is used to measure the blood pressure, cardiac output, oxygen saturation and autonomic functions. However, many studies had developed the algorithms from PPG waveform, making it a potential tool to assess the CVD risk such as arterial stiffness, hypertension and vascular aging (Elgendi 2012; Chellappan et al. 2007). Algorithms such as reflection index, stiffness index (Brillante et al. 2008) and alternative augmentation index (Rubins et al. 2008) had been developed from the PPG signal contour.
Those algorithms represent the vascular compliance or stiffness (Elgendi 2012). Other studies had formed the first and second derivatives PPG (SDPPG) from the PPG waveform signal in order to ease the interpretation. The latter derivative was frequently used in the studies in which it consist of a,b,c,d and e waves. Using the waves height, the ratio of $\mathrm{b} / \mathrm{a}, \mathrm{c} / \mathrm{a}, \mathrm{d} / \mathrm{a}$ and e/a indices were established and previous studies showed association to arterial stiffness (Grabovskis et al. 2011).

Another form of PPG waveform algorithm that has been established is the PPG Fitness Index (PPGF). The algorithm calculates the difference in the PPG waveform contour of the subject to the reference PPG waveform. The reference is obtained from a 19-year-old healthy person with gender-specific (Figure 1) (Chellappan et al. 2008). The researcher also developed Vascular Risk Prediction Index (VRPI) from PPGF derivative. The detail of VRPI had been explained by Aminuddin et al. (2016). The study was conducted on young man below 40 years old and it was found that VRPI had $80 \%$ sensitivity to detect those who had CVD risk factors (Aminuddin et al. 2016). However, data on PPGF and VRPI among young Malaysian women are still lacking. Hence, the objective of this study was to compare PPGF level among young women with and without CVD risk factors and to investigate the relationship between PPGF and other CVD risk markers. In addition, the current study will determine the VRPI sensitivity in classifying young women with CVD risk factors.

\section{MATERIALS AND METHODS}

\section{SUBJECTS}

This study was approved by the Ethics Committee of Universiti Kebangsaan Malaysia Medical Centre and a written informed consent was obtained from each subject. The subjects' recruitment involved young women who were healthy or had CVD risk factor. Young women were defined as women age 20-40 years old (Institut Penyelidikan Pembangunan Belia Malaysia (2011)). CVD risk factors were defined as either having hypertension (systolic or diastolic blood pressure $>140 / 90 \mathrm{mmHg}$ or on hypertensive medication (Bell et al. 2015)), dyslipidaemia [total cholesterol $>6.2 \mathrm{mmol} / \mathrm{L}$ (NCEP ATP III 2001) or low density lipoprotein $>4.1 \mathrm{mmol} / \mathrm{L}$ or triglyceride $>1.7$ $\mathrm{mmol} / \mathrm{L}$ or high density lipoprotein $<1.02 \mathrm{mmol} / \mathrm{L}$ (Stone et al. 2005)], abdominal obesity [waist circumference $>80$ cm (Tan et al. 2004)], smoking (Negri et al. 1994) or family history of premature CVD (male $<55$ years old or female $<60$ years who experienced myocardial infarction or sudden cardiac death or revascularisation (Stone et al. 2005)). Exclusion criteria for all subjects were existing CVD, diabetes mellitus and chronic inflammatory disease. These conditions may be associated with advanced vascular damage and could interrupt the screening for an early vascular lesion.

The number of required sample was 50 subjects for each group. The calculation was based on a published 


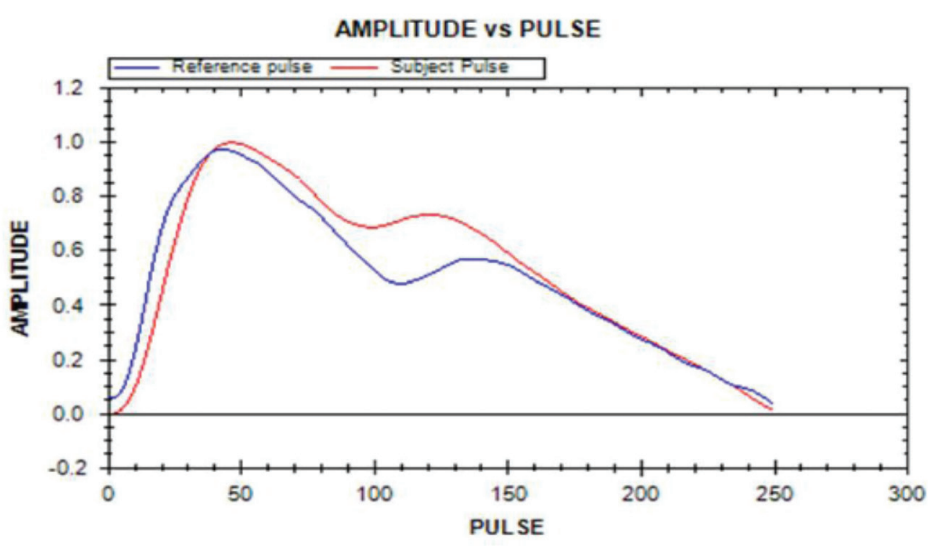

FIGURE 1. PPGF waveform (Blue: 19-year- old healthy reference pulse; Red: target subject) (Chellappan 2008)

formula and information from previous study on PWV (Eng 2003; Pietri et al. 2006). The minimum expected difference between group was $0.09 \mathrm{~m} / \mathrm{s}$, power of study was $80 \%$ and alpha value of 0.05 . For sensitivity study, the minimum required sample was 140 subjects as calculated using formula suggested by Jones et al. (2003) and was based on the prevalence of hypercholesterolemia in Malaysia (Institute for Public Health 2015). Information on socio-demographic includes smoking status, medical history and family history of CVD was collected using a questionnaire. Weight and height were measured using a digital scale and wall-mounted stadiometer respectively (SECA, Germany). The body mass index was calculated as weight $(\mathrm{kg}) /$ height $(\mathrm{m})^{2}$. Waist circumference was measured at the level of iliac crest when the subject was at the end of expiration.

\section{BLOOD PARAMETERS}

Blood samples were taken from a peripheral vein after fasting for at least $8 \mathrm{~h}$. Fasting blood sugar was measured using hexokinase method. Total cholesterol and triglycerides were measured using an enzymatic colorimetric method. High-density lipoprotein was measured using homogenous enzymatic colorimetric while low-density lipoprotein was determined using Friedewald equation. Those tests were carried out at UKM Medical Centre. High sensitivity C Reactive Protein (hs-CRP) was sent to Gribbles Pathology Laboratory and measured using immunoturbidimetric assay.

\section{BRACHIAL AND CENTRAL BLOOD PRESSURE AND AUGMENTATION INDEX (AIx)}

The brachial blood pressure was obtained by using Vicorder System (SMT Medical Wuerzburg, Germany). Measurement is taken in a supine position with a blood pressure cuff placed on the right arm. The system was able to transform brachial waveform into an aortic waveform to estimate central blood pressure by using the brachial-toaortic generalized transfer function. The aortic waveform was used to estimate the augmentation pressure (AP) and pulse pressure (PP). Augmentation index was calculated as $(\mathrm{AP} / \mathrm{PP}) \times 100$ and expressed in percentage (Laurent et al. 2007).

\section{CAROTID-FEMORAL PULSE WAVE VELOCITY $\left(\mathrm{PWV}_{\mathrm{cf}}\right)$}

Subjects were studied in a supine position with head propped up at $45^{\circ}$. Neck and thigh cuff was placed around the common carotid area and upper thigh, respectively (Vicoder System, SMT Medical Wuerzburg, Germany). $\mathrm{PWV}_{\text {cf }}$ was calculated as the distance (D) over transit time (T) $(\mathrm{m} / \mathrm{s})$. The distance was defined as the length of the suprasternal notch and mid-thigh cuff. It was measured using a tape over the surface of the body. Transit time was defined as the time interval between carotid and femoral pulse wave using a foot-to-foot method.

\section{PHOTOPLETHYSMOGRAPHY FITNESS INDEX (PPGF) AND VASCULAR RISK PREDICTION INDEX}

PPGF was measured in supine position with temperature ranging from $20-25^{\circ} \mathrm{C}$. Subjects were asked to rest for $5 \mathrm{~min}$. A finger probe was attached to the right index finger and recording was done for $2 \mathrm{~min}$. A serial port of pulse-oximeter modules was used to capture the signals (NiVARix 1.0, Universiti Kebangsaan Malaysia) and transferred to software established by the manufacturer of NiVARix 1.0. PPGF readings were generated from realtime PPG signal and age. The software also generated an estimation of vascular risk prediction index (VRPI). The result was in a categorical form of very low risk, low risk, moderate risk and high risk that represent the possibility of encountering CVD risk factors.

\section{STATISTICAL ANALYSIS}

Statistical Package for the Social Sciences (SPSS) version 20 was used for data analysis. Kolmogorov-Smirnov test was used to determine the normality of the parameters. All the data were normally distributed except hs-CRP. Hs-CRP values were log transformed to get a normal distribution and was used for data analysis. All the data were expressed 
as mean and standard deviation except hs-CRP that was expressed as median (interquartile range). Comparison between groups were analyzed using independent t-test. The univariate general linear model analysis was used to adjust the confounders (such as age) in determining the difference level of vascular markers between the groups. Previous studies showed that age and race had significant effect on vascular properties (Al-Naamani et al. 2016; Aminuddin et. al 2013), while heart rate was a relevant confounder for PWV and AIx (Laurent et al. 2007). Other study showed that height was a confounding factor for AIx (Janner et al. 2012). Pearson correlation ( $r$ ) was used to determine the associations among vascular markers. Multiple linear regression was performed to assess the independent variables for PPGF.

\section{SENSITIVITY AND SPECIFICITY ANALYSIS}

VRPI sensitivity was calculated as (True positive (TP)/ $(\mathrm{TP}+$ false negative $)] \times 100$ while specificity calculated as [True negative $(\mathrm{TN}) /(\mathrm{TN}+$ false positive $)] \times 100$. It is used to determine the sensitivity and specificity of VRPI in detecting those who had CVD risk factor. VRPI result of moderate and high risk were categorized as positive result while very low and low risk were categorized as negative result (Table 1) (Aminuddin et al. 2016). The classifications of TP, TN, false negative and false positive of the subjects are shown in Table 1 (Aminuddin et al. 2016).

\section{RESULTS}

Table 2 shows the characteristics of the subjects consisting of 148 young women with mean age of $29.97 \pm 5.27$ years old. Generally, the mean of brachial blood pressure, profile lipid and fasting blood sugar for all subjects, healthy group $(\mathrm{HG})$ and risk factor group $(\mathrm{RG})$ group were in normal level. However, the mean body mass index (BMI) for all subjects and RG group were exceeding normal level $\left(>25 \mathrm{~kg} / \mathrm{m}^{2}\right)$. The RG group had higher mean of BMI, waist circumference (WC), brachial systolic blood pressure (bSBP), brachial diastolic blood pressure (bDBP) and lipid profiles (except high-density lipoprotein (HDL) that showed decreased level) compared to HG group. The level of hs-CRP was also increased in the RG when compared to HG $(p<0.001)$.

The level of vascular markers among the HG and RG were summarized in Table 3. Statistical analysis showed that the RG had a significantly higher level of $\operatorname{PWV}(p<0.01)$ and AIX $(p=0.01)$ when compared to HG. These remained significant after adjustment for several confounders. For PPGF, there was no difference observed between the groups.

The association between PPGF with CVD risk factors and other vascular markers are shown in Table 4. PPGF was significantly correlated with age (inverse correlation). After adjustment for the age, PPGF correlated with bDBP, bMAP and PWV. Multiple linear regression showed that PWV $(\beta=-0.31, p<0.001)$ and height $(\beta=0.16, p=0.04)$ are the independent predictors for PPGF (Table 5).

TABLE 1. Subject's classification based on clinical characteristic and VRPI results for sensitivity and spesifisity analysis

\begin{tabular}{lcc}
\hline Subject's characteristic & VRPI results & Classification \\
\hline Have any CVD risk factor & positive & True positive \\
Have any CVD risk factor & negative & False negative \\
No CVD risk factor & positive & False positive \\
No CVD risk factor & negative & True negative \\
\hline
\end{tabular}

Positive $=$ moderate $/$ high risk, negative $=$ very low risk $/$ low risk

TABLE 2. Anthropometric and biochemical characteristics of the subjects

\begin{tabular}{|c|c|c|c|c|c|}
\hline Parameters & $\begin{array}{l}\text { All subject } \\
(n=148)\end{array}$ & $\begin{array}{c}\mathrm{HG} \\
(n=71)\end{array}$ & $\begin{array}{c}\mathrm{RG} \\
(n=77)\end{array}$ & $P$ value & $\begin{array}{c}\text { Reference } \\
\text { range }\end{array}$ \\
\hline Age (years) & $29.97 \pm 5.27$ & $28.91 \pm 4.93$ & $30.95 \pm 5.40$ & 0.02 & - \\
\hline BMI $\left(\mathrm{kg} / \mathrm{m}^{2}\right)$ & $25.03 \pm 5.92$ & $21.51 \pm 3.61$ & $28.27 \pm 5.80$ & $<0.001$ & $<25$ \\
\hline $\mathrm{WC}(\mathrm{cm})$ & $78.35 \pm 12.47$ & $70.53 \pm 6.57$ & $85.56 \pm 12.31$ & $<0.001$ & $\leq 80$ \\
\hline HR (bpm) & $71.29 \pm 11.41$ & $70.62 \pm 11.10$ & $71.91 \pm 11.73$ & 0.49 & $50-100$ \\
\hline bSBP (mmHg) & $120.55 \pm 11.65$ & $116.56 \pm 9.47$ & $124.22 \pm 12.29$ & $<0.001$ & $<140$ \\
\hline bDBP (mmHg) & $67.72 \pm 8.28$ & $65.17 \pm 7.38$ & $70.08 \pm 8.41$ & $<0.001$ & $<90$ \\
\hline $\mathrm{TC}(\mathrm{mmol} / \mathrm{L})$ & $5.03 \pm 0.93$ & $4.82 \pm 0.66$ & $5.20 \pm 1.10$ & 0.02 & $<6.20$ \\
\hline TG (mmol/L) & $0.91 \pm 0.05$ & $0.72 \pm 0.23$ & $1.08 \pm 0.71$ & $<0.001$ & $<1.70$ \\
\hline HDL (mmol/L) & $1.54 \pm 0.03$ & $1.64 \pm 0.28$ & $1.45+0.33$ & $<0.001$ & $\geq 1.04$ \\
\hline $\mathrm{LDL}(\mathrm{mmol} / \mathrm{L})$ & $3.07 \pm 0.07$ & $2.87 \pm 0.60$ & $3.27 \pm 0.99$ & $<0.01$ & $\leq 4.13$ \\
\hline FBS (mmol/L) & $4.59 \pm 0.03$ & $4.53 \pm 0.31$ & $4.65 \pm 0.48$ & 0.07 & $\leq 7.00$ \\
\hline Hs-CRP (mg/L) & $2.36(3.45)$ & $1.29(1.00)$ & $3.34(5.05)$ & $<0.001$ & $<3.00$ \\
\hline
\end{tabular}

Data are expressed in mean $\pm \mathrm{SD}$, except hs-CRP median (interquartile range)

$\mathrm{BMI}=$ body mass index, $\mathrm{WC}=$ waist circumference, $\mathrm{HR}=$ heart rate, $\mathrm{bSBP}=$ brachial systolic blood pressure, $\mathrm{bDBP}=$ brachial diastolic blood pressure, $\mathrm{TC}=$ total cholesterol, $\mathrm{TG}=$ triglyceride, $\mathrm{LDL}=$ low density lipoprotein, $\mathrm{FBS}=$ fasting blood sugar, hs-CRP=High sensitivity $\mathrm{C}$-reactive protein 
TABLE 3. Vascular markers among young women with and without CVD risk factors

\begin{tabular}{|c|c|c|c|c|}
\hline Parameters & All subjects (148) & $\begin{array}{l}\mathrm{HG} \\
(71)\end{array}$ & $\begin{array}{l}\text { RG } \\
(77)\end{array}$ & $P$ value \\
\hline $\mathrm{PWV}_{\mathrm{cf}}\left(\mathrm{ms}^{-1}\right)$ & $6.85 \pm 0.91$ & $6.64 \pm 0.73$ & $7.03 \pm 1.01$ & $\begin{array}{c}<0.01^{*} \\
0.04^{* *} \\
0.04^{\$} \\
0.04^{\#} \\
0.04^{@}\end{array}$ \\
\hline $\operatorname{AIx}(\%)$ & $15.24 \pm 5.94$ & $13.96 \pm 5.03$ & $16.41 \pm 6.47$ & $\begin{array}{c}0.01^{*} \\
0.08^{* *} \\
0.07^{\$} \\
0.06^{\#} \\
0.03^{@}\end{array}$ \\
\hline PPGF $(\%)$ & $48.79 \pm 8.91$ & $49.37 \pm 9.53$ & $48.26 \pm 8.31$ & $\begin{array}{c}0.45^{*} \\
0.71^{* *} \\
0.72^{\$} \\
0.70^{\#} \\
0.70^{\circledR}\end{array}$ \\
\hline
\end{tabular}

Data are mean \pm SD,$*$ unadjusted, ${ }^{* *}$ after adjusted for age, ${ }^{\$}$ after adjusted for age and race, ${ }^{*}$ after adjusted for age, race and height, ${ }^{\circledR}$ after adjusted for age, race, height and heart rate. $\mathrm{PWV}_{\mathrm{cf}}=$ Carotid-femoral Pulse wave velocity, AIx = Augmentation Index, PPGF $=$ Finger photophlethysmography fitness index

TABLE 4. Association between PPGF with vascular markers and CVD risk factors

\begin{tabular}{lcc}
\hline & PPGF & $\begin{array}{c}\text { PPGF } \\
\text { Age adjusted }\end{array}$ \\
\hline Age & $-0.168^{*}$ & - \\
Weight & 0.093 & 0.100 \\
Height & 0.157 & 0.093 \\
BMI & 0.055 & 0.079 \\
WC & 0.018 & 0.015 \\
HR & -0.084 & -0.154 \\
bSBP & -0.134 & -0.133 \\
bDBP & $-0.288^{* *}$ & $-0.310 * *$ \\
bMAP & $-0.205^{*}$ & $-0.194 *$ \\
TC & 0.024 & -0.047 \\
TG & -0.053 & -0.053 \\
HDL & -0.029 & -0.057 \\
LDL & 0.069 & 0.008 \\
FBS & $-0.228 * *$ & -0.181 \\
PWV & $-0.309 * *$ & $-0.255^{* *}$ \\
AIx & -0.076 & 0.015 \\
Log hs-CRP & -0.049 & -0.068 \\
\hline
\end{tabular}

Valus are Pearson correlation $r$ $* P<0.05$

$* * P<0.005$

TABLE 5. Multiple regression analysis for PPGF

\begin{tabular}{lcc}
\hline Variable & $\beta$ & $P$ value \\
\hline PWV $_{\text {cf }}\left(\mathrm{m} / \mathrm{s}^{-1}\right)$ & -0.31 & $<0.001$ \\
Height $(\mathrm{cm})$ & 0.16 & 0.04 \\
\hline
\end{tabular}

Sensitivity analysis showed that the sensitivity of VRPI in identifying young women that has CVD risk factors was $77.9 \%$ and the specificity was $19.7 \%$. Therefore, VRPI had high sensitivity but low specificity in detecting young women that have CVD risk factors.

\section{DISCUSSION AND CONCLUSION}

PPGF is based on finger PPG wave analysis and is a new algorithm for vascular risk assessment (Chellappan et al. 2008). Limited study has been conducted among men and women subjects aged 19-68 years old in Malaysia (Chellappan et al. 2008; Chellappan 2009). Another previous study on PPGF was carried out among young men with and without CVD risk factor (Aminuddin et al. 2016). Therefore, this study focused on the PPGF measurement among young women with and without CVD risk factor. The results showed that there was no difference in PPGF observed between the healthy group (HG) and the risk group (RG). This finding was similar with the study by Aminuddin et al. (2016) that used the same PPG algorithm and age range, but involved young men. The current finding was in contrast with previous studies that used PPG but with different algorithms such as stiffness index and second derivatives PPG (Gunarathne et al. 2008; Hashimoto et al. 2005; Tsai et al. 2005). Study by Hashimoto et al. (2005) in Japan demonstrated increased d/a and decreased $\mathrm{b} / \mathrm{a}$ indices in hypertensive subjects when compared to normotensive subjects. Another study in United Kingdom showed increased in stiffness index among person who had established CVD risk factors such as diabetes mellitus, hypertension and hypercholesterolaemia (Gunarathne et al. 2008). Tsai et al. (2005) estimated the value of PWV by using dual-channel PPG system (PWV-DVP). They found that the PWV-DVP level was increased in hypertensive and 
hypercholesterolemic subjects in China. Another study done in Malaysia by Usman et al. (2014) measured the area under curve of PPG signal (Auc-PPG) among diabetic patients. The patients were categorized into groups of $\mathrm{HbAl}<<8$ and $\mathrm{HbAlc}>10 \%$. They found that Auc-PPG level was lower among the group with higher level of HbA1c. The discrepancy between the current study and previous studies may be due to the different age range and the severity of CVD risk factors. The current study was carried out on young subjects aged 20-40 years old (mean age $=29.97 \pm 5.27$ years old) who were non-diabetic. Previous studies were carried out on much older subjects with mean age of $60.2 \pm 11.2$ years old (Hashimoto et al. 2005), 55.2+10.3 years old (Gunarathne et al. 2008), $38 \pm 10$ years old (Tsai et al. 2005 ) and $58.17 \pm 5.36$ years old (Usman et al. 2014) and those studies included diabetes mellitus as CVD risk factors.

Based on Pearson analysis, there was an association between PPGF and PWV. This association still remains significant in multiple regression analysis. A study by Wowern et al. (2015) that was conducted on subjects with age range of 21-84 years old found that there was a correlation between PWV with aging index (AI) $(r=0.64)$ obtained from the second derivative of the finger photoplethysmogram (SDPPG) indices. The result of this study was also similar with the study by Aminuddin et al. (2016) in which they used the same PPGF algorithm. Aminuddin et al. (2016) showed that PPGF was independently correlated to PWV $(r=-0.27)$. Therefore, the finding in the present study could strengthen their suggestion that PPGF may have potential to be an arterial stiffness marker.

The present study showed no association between PPGF and AIx, which is also another form of arterial stiffness marker. The current finding support the previous study by Aminuddin et al. (2016) that reported no association was found between PPGF and AIx. In contrast, previous studies found an association between PPG and AIx (Wowern et al. 2015; Pilt et al. 2014). Wowern et al. (2015) found an association between aging index and AIx $(r=0.77)$ while Pilt et al. (2014) showed an association between PPG waveform index (PPGAI) and AIx $(r=0.85)$. These studies were carried out on wider age range; 21-66 years old (Pilt et al. 2014) and 21-84 years old (Wowern et al. 2015). In addition, they include subjects with diabetes mellitus (Pilt et al. 2014) and pregnant women (Wowern et al. 2015). Therefore, those factors may contribute to the discrepancies in findings compared to the current study and Aminuddin et al. (2016).

The different association between PWV and AIx towards PPGF might be due to the different feature of the arterial stiffness markers (Yanai 2016). PWV depends on arterial distensibility (Balci et al. 2010) while AIx was based on wave reflection and reflection site, which is affected by several factors such as heart rate, height of the subjects and the PWV itself (Ring et al. 2014).

In our study, no correlation was observed between PPGF and CRP. This finding is similar with previous studies
(Aminuddin et al. 2014; Arnold et al. 2017; Kawada \& Otsuka 2013). There was a suggestion that the effect of inflammation on arterial stiffness occurs after a longterm period. This is further supported by the relationship between CRP and arterial stiffness which exist after more than 16 years (Arnold et al. 2017; Johansen et al. 2012). In the current study, the subjects were relatively young and were newly diagnosed with the risk factor.

For VRPI, there was limited study done to determine its' sensitivity in identifying young subjects with CVD risk factor. Only one study had been conducted, but this was carried out on young men (Aminuddin et al. 2016). In the current study, the sensitivity of VRPI in detecting young women with CVD risk factor was $77.9 \%$ and the specificity was $19.7 \%$. This finding is similar to Aminuddin et al. (2016) that achieved high sensitivity and low specificity of VRPI among young men. Sensitivity is the ability of VRPI to correctly detect the subject that has CVD risk factors while specificity is the ability of VRPI to correctly classify those without CVD risk factors. The high sensitivity of VRPI showed that this method hardly misdiagnosed those with a positive result. Therefore, this method can be used to screen young women with possible CVD risk factors. It is suggested that those with a positive result (moderate and high risk) should undergo further evaluation of CVD risks such as BP measurement, lipid profile examination and diabetic screening. This result emphasizes the previous suggestion that VRPI can be used to determine early vascular changes due to presence of CVD risk factor (Aminuddin et al. 2016). Furthermore, this tool is simple, noninvasive and mobile and could aid in screening CVD risk factor among young people.

In the present study, we measured the level of CVD risk markers such as PWV, AIx, CRP and PPGF among young women with CVD risk factors. This finding may add information to previous studies as the studies involving young women are lacking. The limitation of this study is that we focused on young women for PPGF and VRPI assessment. Therefore, the results may not be applicable for adolescent and elderly women. Since this is a crosssectional study, we are unable to identify the changes of those markers after a certain period of time.

In conclusion, PPGF is correlated with PWV, which has potential to be the marker of aortic stiffness and VRPI is sensitive to identify young women with CVD risk factor.

\section{ACKNOWLEDGEMENTS}

This study was supported by Pusat Perubatan Universiti Kebangsaan Malaysia (PPUKM) grant (FF-2014-011). The author also would like to thank the Cardiovascular and Health Performance Index (CAHPI) group from Physiology Department, PPUKM for their cooperation in recruiting the subjects.

\section{REFERENCES}

Allen, J. 2007. Photoplethysmography and its application in clinical physiological measurement. Physiological Measurement 28: R1-R39. 
Al-Naamani, N., Chirinos, J.A., Zamani, P., Ruthazer, R., Paulus, J.K., Roberts, K.E., Barr, R.G., Lima, J.A., Bluemke, D.A., Kronmal, R. \& Kawut, S.M. 2016. Association of systemic arterial properties with right ventricular morphology: The multi-ethnic study of atherosclerosis (MESA)-right ventricle study. Journal of the American Heart Association 5(12): 11. doi:10.1161/jaha.116.004162[17.10.2016].

Aminuddin, A., Zaiton, Z., Chellappan, K., Azizah, U., Norizam, S. \& Anita, N.M. 2016. The assessment of finger photoplethysmography fitness index (PPGF) among young men with cardiovascular disease risk factors: A cross sectional study. Medicine and Health-Kuala Lumpur 11(2): 218-231.

Aminuddin, A., Chellappan, K., Maskon, O., Zakaria, Z., Karim, A.A., Ngah, W.Z. \& Nordin, N.A.M. 2014. Augmentation index is a better marker for cardiovascular risk in young Malaysian males. A comparison of involvement of pulse wave velocity, augmentation index, and C-reactive protein. Saudi Medical Journal 35(2): 138-146.

Aminuddin, A., Zakaria, Z., Fuad, A.F., Kamsiah, J., Othman, F., Das, S., Kamisah, Y., Qodriyah, H.S., Jubri, Z., Nordin, N.A.M. \& Ngah, W.Z. 2013. High C reactive protein associated with increased pulse wave velocity among urban men with metabolic syndrome in Malaysia. Saudi Medical Journal 34(3): 266-275.

Arnold, N., Gori, T., Schnabel, R.B., Schulz, A., Prochaska, J.H., Zeller, T., Binder, H., Pfeiffer, N., Beutel, M., Espinola-Klein, C. \& Lackner, K.J. 2017. Relation between arterial stiffness and markers of inflammation and hemostasis-data from the population-based Gutenberg Health Study. Scientific Reports (7)10: 6346. doi:10.1038/s41598-017-06175-2.

Balci, H., Demirkok, S.S., Yildiz, M., Metin, G., Hacibekiroglu, M. \& Simsek, G. 2010. The relationship between the inflammatory markers and arterial distensibility in patients with sarcoidosis. Medical Journal of Trakya University 27(1): 44-50.

Bell, K., Twiggs, J. \& Olin, B.R. 2015. Hypertension: The Silent Killer: Updated JNC-8 Guideline Recommendations. United State. Alabama Pharmacy Association.

Borhanuddin, B., Ahmad, N., Shah, S.A., Murad, N.A.A., Zakaria, S.Z.S., Kamaruddin, M.A., Jalal, N.A., Yusuf, N.A.M., Patah, A.E.A., Dauni, A., Sallam, W.A.F.W. \& Jamal, R. 2018. Association of job sectors with type 2 diabetes mellitus, hypercholesterolemia and obesity: A cross-sectional study from the Malaysian Cohort (TMC) project. International Health. 9. doi:10.1093/inthealth/ihx075.

Brillante, D.G., O’sullivan, A.J. \& Howes, L.G. 2008. Arterial stiffness indices in healthy volunteers using non-invasive digital photoplethysmography. Blood Pressure 17(2): 116123.

Chellappan, K. 2009. Noninvasive vascular risk prediction by photophlethymogram analysis. Thesis Ph.D. Universiti Kebangsaan Malaysia (Unpublished).

Chellappan, K., Mohd Ali, M.A. \& Zahedi, E. 2008. An age index for vascular system based on photoplethysmogram pulse contour analysis. In $4^{\text {th }}$ Kuala Lumpur International Conference on Biomedical Engineering 2008(21): 125-128.

Chellappan, K., Zahedi, E. \& Ali, M.A.M. 2007. Age-related upper limb vascular system windkessel model using photoplethysmography. In 3rd Kuala Lumpur International Conference on Biomedical Engineering 2006. Springer, Berlin: Heidelberg. pp. 563-566.

Chin, C.Y. \& Pengal, S. 2009. Cardiovascular disease risk in a semirural community in Malaysia. Asia Pacific Journal of Public Health 21(4): 410-420.
Chirinos, J.A., Kips, J.G., Jacobs Jr., D.R., Brumback, L., Duprez, D.A., Kronmal, R., Bluemke, D.A., Townsend, R.R., Vermeersch, S. \& Segers, P. 2012. Arterial wave reflections and incident cardiovascular events and heart failure: MESA (Multiethnic study of atherosclerosis). Journal of the American College of Cardiology 60(21): 2170-2177.

DeFilippis, A.P., Blaha, M.J., Ndumele, C.E., Budoff, M.J., LloydJones, D.M., McClelland, R.L., Lakoski, S.G., Cushman, M., Wong, N.D., Blumenthal, R.S., Lima, J. \& Nasir, K. 2011. The association of Framingham and Reynolds risk scores with incidence and progression of coronary artery calcification in MESA(Multi-ethnic study of atherosclerosis). Journal of the American College of Cardiology 58(20): 2076-2083.

Elgendi, M. 2012. On the analysis of fingertip photoplethysmogram signals. Current Cardiology Reviews 8(1): 14-25.

Eng, J. 2003. Sample size estimation: How many individuals should be studied? Radiology 227(2): 309-313.

Gafor, A.H.A., Mohd, R., Cader, R., Yen, K.W., Mohamad, M., Shah, S.A., Bain, A. \& Kong, N.C. 2018. Evaluating cardiovascular risk in chronic kidney disease patients: A biomarker approach. Sains Malaysiana 47(1): 149-155.

Gamil, S.S., Adam, M.E. \& Bakheit, K.H. 2014. Plasma levels of C-reactive protein a cardiovascular risk factor indicator in Sudanese overweight and obese adults. Journal of Endocrinology, Diabetes \& Obesity 3(1): 1063.

Gunarathne, A., Patel, J.V., Hughes, E.A. \& Lip, G.Y. 2008. Measurement of stiffness index by digital volume pulse analysis technique: Clinical utility in cardiovascular disease risk stratification. American Journal of Hypertension 21(8): 866-872.

Gupta, S., Gudapati, R., Gaurav, K. \& Bhise, M. 2013. Emerging risk factors for cardiovascular diseases: Indian context. Indian Journal of Endocrinology and Metabolism 17(5): 806-814.

Grabovskis, A., Marcinkevics, Z., Lukstina, Z., Majauska, M., Aivars, J., Lusa, V. \& Kalinina, A. 2011. Usability of photoplethysmography method in estimation of conduit artery stiffness. In European Conference on Biomedical Optics (p. 80900X). Optical Society of America.

Hashimoto, J., Watabe, D., Kimura, A., Takahashi, H., Ohkubo, T., Totsune, K. \& Imai, Y. 2005. Determinants of the second derivative of the finger photoplethysmogram and brachialankle pulse-wave velocity: The Ohasama study. American Journal of Hypertension 18(4): 477-485.

Institute for Public Health (IPH). 2015. National Health and Morbidity Survey 2015 (NHMS 2015). Vol. II: NonCommunicable Diseases, Risk Factors \& Other Health Problems.2. Kuala Lumpur. Ministry of Health Malaysia.

Institut Penyelidikan Pembangunan Belia Malaysia. 2011. Indeks Belia Malaysia 2011.96 https://www.ippbm.gov.my/ dokumen/IBM2011.pdf.

Janner, J.H., Godtfredsen, N.S., Ladelund, S., Vestbo, J. \& Prescott, E. 2012. The association between aortic augmentation index and cardiovascular risk factors in a large unselected population. Journal of Human Hypertension 26(8): 476-484.

Johansen, N.B., Vistisen, D., Brunner, E.J., Tabák, A.G., Shipley, M.J., Wilkinson, I.B., McEniery, C.M., Roden, M., Herder, C., Kivimäki, M. \& Witte, D.R. 2012. Determinants of aortic stiffness: 16-year follow-up of the Whitehall II study. PloS One 7(5). doi.org/10.1371/journal.pone.0037165.

Jones, S.R., Carley, S. \& Harrison, M. 2003. An introduction to power and sample size estimation. Emergency Medicine Journal 20(5): 453-458. 
Kawada, T. \& Otsuka, T. 2013. Factor structure of indices of the second derivative of the finger photoplethysmogram with metabolic components and other cardiovascular risk indicators. Diabetes \& Metabolism Journal 37(1): 40-45.

Kuklina, E.V., Yoon, P.W. \& Keenan, N.L. 2010. Prevalence of coronary heart disease risk factors and screening for high cholesterol levels among young adults, United States, 19992006. The Annals of Family Medicine 8(4): 327-333.

Kuznetsova, T., Vlierberghe, E.V., Knez, J., Szczesny, G., Thijs, L., Jozeau, D., Balestra, C. \& Staessen, J.A. 2014. Association of digital vascular function with cardiovascular risk factors: A population study. British Medical Journal 4(3): 1-9. doi:10.1136/bmjopen-2013-004399.

Laurent, S., Cockcroft, J., Van Bortel, L., Boutouyrie, P., Giannattasio, C., Hayoz, D., Pannier, B., Vlachopoulos, C., Wilkinson, I. \& Struijker-Boudier, H. 2007. Abridged version of the expert consensus document on arterial stiffness. Artery Research 1(1): 2-12.

Luo, K.Q., Feng, X.W., Xu, B.C. \& Long, H.B. 2014. Association between arterial stiffness and risk of coronary artery disease. Pakistan Journal of Medical Sciences 30(6): 1314-1318.

National Cholesterol Education Program (NCEP) Expert Panel on Detection, Evaluation and Treatment of High Blood Cholesterol in Adults (ATP III). 2001. Executive summary of the Third Report of the National Cholesterol Education Program (NCEP) expert panel on detection, evaluation, and treatment of high blood cholesterol in adults (Adult Treatment Panel III). The Journal of the American Medical Association 285(19): 2486-2497.

Negri, E., La Vecchia, C., D’Avanzo, B., Nobili, A. \& La Malfa, R.G. 1994. Acute myocardial infarction: Association with time since stopping smoking in Italy. GISSI-EFRIM Investigators. Gruppo Italiano per lo Studio della Sopravvivenza nell'Infarto. Epidemiologia dei Fattori di Rischio dell'Infarto Miocardico. Journal of Epidemiology \& Community Health 48(2): 129-133.

Pilt, K., Meigas, K., Ferenets, R., Temitski, K. \& Viigimaa, M. 2014. Photoplethysmographic signal waveform index for detection of increased arterial stiffness. Physiological Measurement 35(10): 2027-2036.

Pietri, P., Vyssoulis, G., Vlachopoulos, C., Zervoudaki, A., Gialernios, T., Aznaouridis, K. \& Stefanadis, C. 2006. Relationship between low-grade inflammation and arterial stiffness in patients with essential hypertension. Journal of Hypertension 24(11): 2231-2238.

Ring, M., Eriksson, M.J., Zierath, J.R. \& Caidahl, K. 2014. Arterial stiffness estimation in healthy subjects: A validation of oscillometric (Arteriograph) and tonometric (SphygmoCor) techniques. Hypertension Research 37(11): 999-1007.

Rubins, U., Grabovskis, A., Grube, J. \& Kukulis, I. 2008. Photoplethysmography analysis of artery properties in patients with cardiovascular diseases. 14th Nordic-Baltic Conference on Biomedical Engineering and Medical Physics 20: 319-322

Stone, N.J., Bilek, S. \& Rosenbaum, S. 2005. Recent national cholesterol education program adult treatment panel III update: Adjustments and options. The American Journal of Cardiology 96(4): 53-59.

Shyam, S., Arshad, F., Ghani, R.A., Wahab, N.A., Chinna, K., Safii, N.S., Nisak Y.B. \& Kamaruddin, N.A. 2014. Metabolic syndrome, abnormal glucose tolerance and high sensitivity-CReactive protein among women with a history of gestational diabetes mellitus. Journal of Diabetes \& Metabolism 5(9): 6. doi: 10.4172/2155-6156.1000424.

Tabara, Y., Igase, M., Okada, Y., Nagai, T., Miki, T., Ohyagi, Y., Matsuda, F. \& Kohara, K. 2016. Usefulness of the second derivative of the finger photoplethysmogram for assessment of end-organ damage: The J-SHIPP study. Hypertension Research 39(7): 552-556.

Tan, C.E., Ma, S., Wai, D., Chew, S.K. \& Tai, E.S. 2004. Can we apply the national cholesterol education program adult treatment panel definition of the metabolic syndrome to Asians? Diabetes Care 27(5): 1182-1186.

Tsai, W.C., Chen, J.Y., Wang, M.C., Wu, H.T., Chi, C.K., Chen, Y.K., Chen, J.H. \& Lin, L.J. 2005. Association of risk factors with increased pulse wave velocity detected by a novel method using dual-channel photoplethysmography. American Journal of Hypertension 18(8): 1118-1122.

Usman, S., Reaz, M.I. \& Ali, M.M. 2014. Measuring arterial stiffness using photoplethysmogram. Acta Scientiarum Technology 36(1): 123-128.

World Health Organization (WHO). 2017. Cardiovascular diseases (CVDs): Fact sheet. World Health Organization http://www.who.int/mediacentre/factsheets/fs317/en/.

World Health Organization (WHO). 2014. Noncommunicable Diseases Country Profiles 2014. Geneva: World Health Organization.

World Health Organization (WHO). 2011. Global Atlas on Cardiovascular Disease Prevention and Control, edited by Mendis, S., Puska, P. \& Norrving, B. France: WHO Press.

Wowern, V.E., Östling, G., Nilsson, P.M. \& Olofsson, P. 2015. Digital photoplethysmography for assessment of arterial stiffness: Repeatability and comparison with applanation tonometry. PloS One 10(8): 19. doi:10.1371/journal. pone. 0135659 .

Yanai, H. 2016. Correlations of arterial stiffness and augmentation index with metabolic risk factors in patients with type 2 diabetes. The Journal of Clinical Hypertension 18(6): 593594.

Veeranna, V., Pradhan, J., Niraj, A., Fakhry, H. \& Afonso, L. 2010. Traditional cardiovascular risk factors and severity of angiographic coronary artery disease in the elderly. Preventive Cardiology 13(3): 135-140.

Musilawati Muhajir, Amilia Aminuddin*, Azizah Ugusman, Norizam Salamt, Zanariyah Asmawi, Aini Farzana Zulkefli, Muhammad Firdaus Azmi \& Nor Anita Megat Mohd Nordin Department of Physiology Universiti Kebangsaan Malaysia Medical Center Jalan Yaakob Latiff, Bandar Tun Razak 56000 Cheras, Kuala Lumpur, Federal Territory Malaysia

Musilawati Muhajir

Department of Pathology

Universiti Kebangsaan Malaysia Medical Center

Jalan Yaakob Latiff, Bandar Tun Razak

56000 Cheras, Kuala Lumpur, Federal Territory Malaysia

Kalaivani Chellappan

Faculty of Engineering

Universiti Kebangsaan Malaysia 
43600 UKM Bangi, Selangor Darul Ehsan

Malaysia

*Corresponding author; email: amyyra1234@yahoo.com.my
Received: 17 March 2018

Accepted: 20 June 2018 